\title{
Climate Change Adaptation Mechanism for Sustainable Development Goal 1 in Nigeria: Legal Imperative
}

\author{
Erimma Gloria Orie
}

\section{Contents}

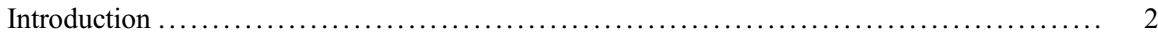

Conceptual Clarification ................................................ 4

Nexus Between CC Adaptation Mechanism and Poverty (SDG 1) ................... 6

Global Efforts to Combat Poverty Through Adaptation Mechanism ................... 8

Policy, Legal, and Institutional Frameworks for Fighting Poverty in Nigeria ........... 10

Legal Issues, Challenges, and Strategies in the Application of Climate Change

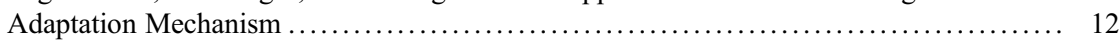

Conclusion and Recommendation ........................................ 17

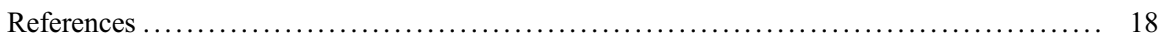

\section{Abstract}

Despite international efforts on poverty reduction in the last decade, poverty is rampant in many countries including Nigeria. Poverty remains a principal challenge for development in twenty-first century and a threat to achievement of Sustainable Development Goal (SDG) 1, which is a global attempt, among others, to end poverty by 2030 . Meanwhile, 13 out of the 15 countries where extreme poverty is rising are in Africa. According to the World Poverty Clock, Nigeria, by 2018 , had the largest extreme poverty population of 86.9 million, thus making the people vulnerable to malnutrition, armed conflict, migration, and other socioeconomic and environmental shocks. Whereas these impacts are exacerbated by climate change (CC), unfortunately, Nigeria's adaptation efforts are inadequate due to certain impediments. The chapter finds that Nigeria lacks the CC law to properly regulate institutional and policy interventions to impacts of CC. It argues that although adaptation as opposed to mitigation is interim, yet integrating adaptation measures into Sustainable Development (SD) framework and poverty reduction strategies is a potent means of addressing $\mathrm{CC}$ impacts on the poor and achieve SDG1 target. The chapter therefore recommends the establishment of CC

E. G. Orie $(\bowtie)$

Department of Private \& Property Law, National Open University of Nigeria, Abuja, Nigeria 
law in Nigeria that incorporates adaptation measures in poverty reduction strategies and mainstreaming of $\mathrm{CC}$ issues.

\section{Keywords}

Poverty · Adaptation · Sustainable development (SD) $\cdot$ Sustainable Development Goals (SDGs) $\cdot$ Climate change (CC)

\section{Introduction}

Since the turn of the twenty-first century, there has been an unrivaled concern of the international community to achieve sustainable development (SD). From Stockholm Declaration through Rio +10 , Agenda 21 to the United Nations Conference on Sustainable Development held in Rio 2012, and the Millennium Development Goals (MDGs), the Paris Agreement, and the recent UN Conference of Parties (COP 24) at Bon, Germany, the focus has been to combat environmental damage and reduce poverty and diseases through global cooperation on common interests, mutual needs, and shared responsibilities. Even the United Nations 2030 Agenda for Sustainable Development is an action plan focused on people, planet, prosperity, peace, and partnership (5Ps) with a mandate that no one should be left behind. The first Sustainable Development Goals' Report published in 2016 (Portugal 2016) reveals that about 1 in every 8 persons in the world still lives in extreme poverty; some 800 million people are suffering from hunger; the birth of nearly 1 in 4 children under the age of 5 years is still unregistered; women spend about 2.4 times more hours per day on caregiving and household tasks than men; 1.1 billion people live without electricity; and that water scarcity now affects more than 2 billion people in the world (Ibid). Furthermore, the UN has launched the 2018 version of the yearly Sustainable Development Goals (SDGs) Report (SDG Report 2018) which finds that conflict, climate change, and inequality are major factors in growing hunger and displacement, and are hindering progress toward the SDGs. The implication of these reports is that the world, particularly Africa and of course, Nigeria, is not on course to ending poverty at least by 2030 . This could undermine the attainment of SDG 1 which deals with poverty reduction.

The major objective of the World Bank since the 1970s has equally been to reduce poverty. In 2013, the World Bank Group announced two all-embracing goals: the end of chronic extreme poverty by 2030; the promotion of shared prosperity, defined in terms of economic growth of the poorest segments of society (to reduce extreme poverty to $3 \%$ of the world population by 2030 and, for the first time, including a distributional goal, "share prosperity" by promoting the income growth of the poorest $40 \%$ ). However, the global proportion of people living in extreme poverty is three times lower than in 1970; it fell from 43\% in 1990 to $19 \%$ in 2010 and further to $17 \%$ in 2011 (Ending Extreme Poverty 2013).

Despite commitments to inclusive, pro-poor, and broad-based growth, the poorest $20 \%$ of people still receive just $1 \%$ of global income causing the gap between the 
poorest $20 \%$ and everyone else to continue to widen. Indeed, 13 out of the 15 countries where extreme poverty is rising are in Africa. According to the World Poverty Clock, by 2018, Nigeria had the largest extreme poverty population of 86.9 million due to drought, flood, heatwaves, ocean surges, reduction in crop yield, decreased fresh water availability, disruption of economic activities, destruction of infrastructure, etc. These challenges are exacerbated by the impact of climate change (Orie 2015), the end state of which is that the people are made vulnerable to malnutrition, armed conflict, migration, and other socioeconomic and environmental shocks. The National Bureau of Statistics figures showed that poverty incidence worsened between 2004 and 2010, despite impressive growth record over this period (Olofin et al. 2015). Poor farmers also risk losing crops as the flood season occurs when crops ripen for harvest. In the longer term, poor households also risk losing wage opportunities as the sick and injured cannot work or as the disaster destroys the need for labor. Recovery strategies, like selling assets, can leave the poor without income and thus more vulnerable.

Nigeria's extreme poverty population of 86.9 million can be scary. Specifically, for Lagos, Osun, Anambra, Ekiti, Edo, Imo, Abia, and Rivers States, the poverty level hovers between 8.5 and 21.1\%; Plateau, Nassarawa, Ebonyi, Kaduna, Adamawa, and Benue States have poverty level that hovers between 51.6 and $59.2 \%$, while the poverty level for Niger, Borno, Kano, Gombe, Taraba, Katsina, Sokoto, Kebbi, Bauchi, Jigawa, Yobe, and Zamfara States hovers between 61.2 and 91.9\% (Olawale 2018). Certainly, these degrees of poverty make the people vulnerable to malnutrition, armed conflict, migration, and other socioeconomic and environmental shocks. Whereas these impacts are exacerbated by climate change, unfortunately, Nigeria's adaptation efforts to counter poverty are inadequate due to certain legal impediments. Nigeria, for instance, lacks the climate change law to properly regulate institutional and policy interventions to impacts of climate change. The crux of the matter is that without a legally binding framework, integrating adaptation measures into SD framework and poverty reduction strategies, it will be difficult to address climate change impacts on the poor and achieve SDG1 target. Moreover, the commitment to all-inclusive zero poverty has no global or national framework of measurement. These are some of the challenges Nigeria has been grappling with and must overcome in order to attain SDG 1 target. Perhaps, leveraging international best practices, the establishment of climate change law in Nigeria that incorporates adaptation measures in poverty reduction strategies could present a way forward and that is the motivation and what this chapter purposes to achieve. The chapter is limited mostly to document analyses of the relevant UN and other international conventions/documentations as well as national policies on the subject matter in the last decade when climate change, MDG, and SDG issues assumed more global attention and priority. The focus of this work remains the legal dimensions to Nigeria's efforts regarding climate change adaptation mechanism.

Therefore, the chapter begins with conceptual clarifications of key words to set the work in proper perspective leading to establishment of nexus between climate change adaptation and poverty. This is followed by a highlight of global efforts to 
combat poverty through Adaptation mechanism. Next is an examination of the policy, legal, and institutional framework for fighting poverty in Nigeria leading to a discussion on the legal issues, challenges, as well as strategies in the application of climate change adaptation mechanism to achieve SDG 1. Thereafter the chapter concludes with salient recommendations.

\section{Conceptual Clarification}

It is necessary to conceptualize the key words in order to put the paper in proper perspective and to aid understanding. The words and phrases to be conceptualized are climate change, sustainable development, adaptation, and poverty.

\section{Climate Change}

The United Nations Framework Convention on Climate Change (UNFCCC) defines climate change as a change of climate which is attributed directly or indirectly to human activity that alters the composition of the global atmosphere and which is in addition to natural climate variability observed over comparable time periods (UNFCCC Art 1.2). The impact of climate change include rise in sea levels, rise in temperature, and change in weather patterns resulting in decline in overall biodiversity, implications for agriculture and food security, human health, unpredictable rain pattern and floods, prolonged drought and subsequent crop failures, water shortages, and homelessness (Orie 2017).

\section{Sustainable Development}

Sustainable development is the universally adopted plan to promote prosperity and social well-being while protecting the environment. The 2030 Agenda for SD is "our shared vision of humanity and a social contract between the world's leaders and the people" (Ban Ki-Moon), which sets an ambitious but achievable, universal, and holistic agenda for all. As a universal agenda, based on 17 SDGs and 169 targets to be implemented by all countries, the 2030 Agenda calls for the integration of the SDGs into the policies, procedures, and actions developed at the national, regional, and global levels. There is a clear call for action to dramatically scale up development finance and improve the development impact of all financial flows. But its goals are at risk of not being realized as the gap between the poorest people and the rest of the world continues to widen.

In several ways, the SDGs brought a novel tactic to the manner in which the world approaches the subject matter of development. These include, for example:

(i) Integrating the three dimensions of SD (economic, social, and environmental).

(ii) Being based on universal goals and targets to be implemented by all countries (and not only by developing countries).

(iii) Having a greater potential for tackling inequality and promoting human rights as a cross-cutting concern across all SDGs. 
(iv) Involving new dynamic concerted efforts from a wide range of actors, including nongovernmental organizations (NGOs), the private corporate sector, academia, social partners, and other members of civil society, including the cooperation between parliament, government, regional, and local authorities. In fact, this is a challenge which concerns us all (Portugal).

\section{Adaptation}

The term adaptation according to the UNFCCC refers to "adjustments in ecologicalsocial-economic systems in response to actual or expected climatic stimuli, their effects or impacts, and the building of a climate-resilient society that is able to withstand or recover quickly from difficult conditions caused by the adverse effects of climate change" (Medugu et al. 2011). Examples of adaptations include building flood defenses, planning for heat waves and higher temperatures, and installing water-permeable pavements to better deal with floods and storm water and improving water storage and use (Ibid; Orie 2015). Adaptation also encompasses making the most of any potential beneficial opportunities associated with climate change (for example, longer growing seasons or increased yields in some regions) (global climate change). However, the major challenge to adaptation includes the fact that adaptation is fundamentally about climate change risk management, and it is not a long-term solution, hence the need for reinforcement which mitigation offers (IPCC report).

A major benefit of adaptation is the fact that it is usually imbued with the prospects of reducing the negative impacts of climate change. However, the capacity to adapt is principally a factor of the socio-economic characteristics, and the likelihood of adaptation needs to be carefully analyzed given the peculiar circumstances of the developing countries and their obvious disadvantage with respect to technological, financial, and institutional provisions (McGuigan et al. 2002).

\section{Poverty}

The World Bank defines extreme poverty as living on less than 1.90 international dollars (int.\$) (Roser and Ortiz-Ospina 2019). Poverty is the result of economic, political, and social processes that interact and frequently reinforce each other in ways that exacerbate the deprivation in which poor people live (Ibid). The United Nations has also now declared the eradication of poverty by 2030 as a primary development goal. Poverty is at the same time stark and conceptually elusive, especially when we try to track it statistically across nations and over time. The World Bank Group has been at the vanguard of developing measures of living standards and it sets the International Poverty Line (IPL). The poverty line was revised in 2015 and since then persons are considered to be in extreme poverty if they live on less than 1.90 (int.-\$) per day. The measurement of this poverty is based on the monetary value of a person's consumption while the application of income measures is employed for countries without available reliable consumption measures (World Bank 2015). Alternative starting points for measuring welfare include subjective views (e.g., self-reported life satisfaction), basic needs (e.g., caloric requirements), capabilities (e.g., access to education), and minimum rights (e.g., 
human rights) (Ibid). There is also the national accounts method to estimate poverty which is based on academic studies that reconstruct historical income levels from cross-country macro estimates on economic output and inequality. Therefore, while the IPL is useful for understanding the changes in living conditions of the very poorest of the world, one must also take into account higher poverty lines reflecting the fact that living conditions at higher thresholds or well above the IPL can still constitute a destitute.

\section{Nexus Between CC Adaptation Mechanism and Poverty (SDG 1)}

The 2007 and 2014 IPCC reports state that due to the effect of climate change, both distributional impacts of increased temperature and precipitation changes will vary from region to region, affecting higher and lower latitudes disparagingly and asymmetrically (IPCC Fourth Assessment Report). The IPCC Report predicts further that global warming resulting from carbon emissions will cause a rise in sea levels and may lead to an increase in the frequency and severity of natural disasters. In addition, incidences of natural disasters such as droughts and floods, which affect agricultural production, fisheries and marine life, water resource availability, industry, and human health will continue to be on the increase and indeed exacerbated by climate change.

Coastal areas are most at risk to the changes outlined above. Increased sea levels will bring salinization and an intrusion of seawater into freshwater sources, flooding and loss of land, erosion, loss of wetlands and mangroves, and loss of soil fertility. Furthermore, changes in temperature will alter ocean circulation patterns, vertical mixing of water and wave patterns which will impact on marine productivity, availability of nutrients, and disturb the structure of marine and coastal ecosystems (IPCC 2001). While there is no data on the frequency of disasters due to climate change, Messer estimates that with a $70 \mathrm{~cm}$ sea level rise, the number of people at risk of annual flooding could increase from 46 million to 90 million. With such disasters come the urge need for interim relief assistance (like artificial irrigation in drought areas) to enable the people adjust to the impact of the disaster. Thus, adaptation enables the victims to access immediate and or interim assistance as opposed to a long-term relief which mitigation provides (Messer 2003).

Furthermore, the disasters are expected to increase the disparity in wealth between the developed and developing world, and redistributive impact is one of the major reasons for concern about the climate change phenomena as expressed by the IPCC in its 2001 report. Due to these differential effects, developing countries like Nigeria are likely to suffer more from the economic impacts of climate change, as well as being the least able to adapt to new climatic conditions. Moreover, poorer communities also have limited means to cope with the losses and damage inflicted by natural disasters. Lack of adaptation option like insurance policies, savings, or credit make it almost impossible to replace or compensate for the numerous things lost or destroyed, including houses, livestock, food reserves, household items, and 
tools (IPCC 2001), which in turn will threaten the chances of effective reduction in poverty level.

Developing countries often do not have the resources for these and consequently are ill-prepared in terms of coastal protection, early warning and disaster response systems, and victim relief and recovery assistance, hence the disproportionate level of climatic impact. For example, it has been asserted in some quarters that even when developed countries experience a larger proportion of property damage $(75 \%)$, that recovery costs are higher for developing countries. Also, that whilst developed countries pay $0.1 \%$ of GDP in losses, developing countries pay $2-3 \%$, or sometimes as much as $15 \%$ as seen with hurricanes in the Caribbean (Gurtner 2010). Developing countries also experience greater loss of life, about $90 \%$ of all deaths (Bankoff 1999). For example, the risk of drowning in Fiji due to dyke failure is one in 100,000 , whereas in the Netherlands it is one in ten million (Olsthoorn et al. 1999). Notwithstanding the degree of risks exacerbated by climate change for these poor and marginalized populations, lots of uncertainties exist for developing countries regarding scientific predictions, levels of vulnerability, and the ability to adapt to these developments. Recent estimates suggest that, in the absence of adaptation, climate change could result in a loss of between $2 \%$ and $11 \%$ of Nigeria's GDP by 2020 , rising to between $6 \%$ and $30 \%$ by the year 2050 . This loss is equivalent to between N15 trillion (US\$100 billion) and N69 trillion (US\$460 billion) (National adaptation strategy). Several legal barriers, poor access to location, lack of services and infrastructure, and poor building structures all increase the vulnerability to flooding, storm surges, drought, and rain. The result is the accentuation of poverty, hunger, lack of quality education, gender inequality, loss of basic shelter, and jobs. These challenges are a threat to both the global and national efforts toward the attainment of the SDGs especially that of eradicating poverty.

The SDGs comprise 17 goals spliced into 169 targets. For example, the focus of SDG \#1 is to end poverty and SDG \#2 is to end hunger. Poverty breads hunger which in turn affects the general well-being of a person by reducing the coping capacity to environmental challenges. A poor man is usually hungry and thus cannot achieve SDG \#3 which is on well-being. When the stomach is empty, nothing can enter the brain, but if the first three goals are achieved, one can make use of SDG \#4 Quality Education and learn to respect others and internalize SDG \#5 Gender Equality. Thus, the SDGs are interrelated and interconnected.

It has been noted that giving priority to SD and meeting the SDGs is in tandem with efforts to adapt to climate change. When SD promotes livelihood security, it enhances the adaptive capacities of vulnerable communities and households. Examples include SDG 2 and its targets that promote adaptation in agricultural and food systems (Lipper et al. 2014) and SDG 11 which supports adaptation in cities to reduce harm from disasters (Kelman 2017). The overall success of SDGs 2 and 11 will assist in reducing poverty which is SDG 1. Indeed it has been submitted by various scholars that a well-integrated adaptation supports sustainable development (Weisser 2014). Substantial synergies are observed in the agricultural and health sectors and in ecosystem-based adaptations. However, a particular adaptation strategy can equally lead to adverse consequences for developmental outcomes. 
Furthermore, adaptation strategies that advance one SDG can result in tradeoffs with other SDGs. For instance, agricultural adaptation to enhance food security (SDG 2) causes negative impacts on health, equality, and healthy ecosystems (SDGs 3, 5, $6,10,14$ and 15). Notwithstanding this important role that adaptation could play to ensure that achievement of SDG 1 remains on course, Nigeria has no climate change law for the implementation of adaptation policy to achieve SDG 1. This is quite a challenge that must be addressed in order to make progress.

This segment has so far established the nexus between climate change adaptation and poverty. It has argued that incidences of natural disasters such as droughts, floods desertification, etc. which continue to increase and indeed are exacerbated by climate change can be checkmated, albeit, in the interim by adaptation measures to ensure the eradication of poverty (attainment of SDG 1) by 2030. In the case of Nigeria, it is therefore imperative that her adaptation measures are strengthened legally to ensure that the stated target is achieved. The next section will examine the global perspective to this.

\section{Global Efforts to Combat Poverty Through Adaptation Mechanism}

There is increasing global efforts to address poverty based on our interconnectedness as peoples living on mother earth and the understanding of the need to save the environment for use by future generations. From around 1820, there was widespread poverty with more than a billion people that lived in extreme poverty, but this has changed over the last two centuries due mainly to economic growth not withstanding that the population increased sevenfold over the same period. According to these household surveys, $44 \%$ of the world population lived in absolute poverty in 1981 , whereas in 32 years, the share of people living in extreme poverty was divided by 4, reaching levels below $11 \%$ in 2013 . There were 2.2 billion people living in extreme poverty in 1970, while people living in extreme poverty in 2015 were 705 million (Roser and Ortiz-Ospina 2019).

The global incidence of extreme poverty has gone down from almost $100 \%$ in the nineteenth century to $10.7 \%$ in 2013 . Some analysts have submitted that this substantial reduction of global poverty is not unconnected with the poverty reduction in China where in 1981 almost one third (29\%) of the non-Chinese world population was living in extreme poverty, but by 2013 , this share had fallen to $12 \%$. Others believe it has to do with sustained economic growth, driven by industrial development and their ability to benefit from globalization. While this is a great achievement, there is absolutely no reason to be complacent: a poverty rate of $10.7 \%$ means a total poverty headcount of about 746 million people (Ibid). The breakdown by continent is as follows: 383 million in Africa, 327 million in Asia, 19 million in South America, 13 million in North America, 2.5 million in Oceania, and 0.7 million in Europe. Africa is the continent with the largest number of people living in extreme poverty. On the other hand, India is the country with the largest number of people living in extreme poverty (218 million people), while Nigeria and the Congo (DRC) follow with 86 and 55 million people, respectively (Ibid). 
In line with the global fight against poverty, it has been suggested in some quarters that the most direct method to measure poverty is to use the poverty headcount ratio. This method requires the setting up of a poverty line and then counting the number of people living with incomes or consumption levels below that poverty line. A major advantage of this system is that it offers information that is candid to interpret; by definition, it shows the percentage of the population living with consumption (or incomes) below some minimum level (Ibid).

The World Bank Group has also published a new set of poverty estimates, as part of their report on poverty and shared prosperity. These estimates, explained in details in two related background papers (Ibid), are consistent with the official World Bank poverty figures published in Povcal and the World Development Indicators, but they are disaggregated by key demographic characteristics such as age and educational attainment. Furthermore, the UN projection through the SDGs is an extremely ambitious target of ending extreme poverty by 2030 , a target which many analysts have observed is likely to require growth with declining inequality. Globally, many governments tend to adopt short-term interventions programs as a means of reducing poverty. In fact, a multilayered program offering short-term support along various household dimensions has been shown to cause lasting progress for the very poor in six different countries. This intervention comprises six elements; a productive asset grant, temporary cash consumption support, technical skills training, high frequency home visits, a savings program, as well as health education and services.

Regionally, the European Union in a show of commitment to the SD across borders published, through the European Commission on November 22, 2016, a Communication on the "Next steps for a sustainable European future" that sets out how the 2030 Agenda is to be implemented within the EU. This internal implementation of the Agenda includes two work streams: the first is to fully integrate the SDGs in the European policy framework and the Juncker Commission's ten priorities for its current term, identifying the most relevant sustainability concerns, and also assessing European policies and the efforts to achieve the 17 Goals, while the second one will work on further developing a long-term European vision and focus on sector-based policies after 2020 which will enable the long-term implementation of the SDGs. The new Multiannual Financial Framework beyond 2020 shall also reorient the EU budget's contributions toward that same end (Ibid). Furthermore, for the external implementation of the 2030 Agenda, the Commission also presented on November 22, 2016 a communication on the review of the European Consensus on Development (2017), seeking to adapt the development policy of the EU to the new international development architecture. European Consensus was adopted in 2017, and it is organized around the 5Ps of the Agenda 2030. It is expected to impact on the elaboration of development instruments and programs of the EU and its Member States, fostering their alignment with the SDGs and the Addis Ababa Action Agenda (Addis Ababa 2015).

The implementation of the Agenda at the national level brings new challenges which require some reshaping of institutional models to reflect and meet the inherent cross-sector coordination requirements. In this process, it is also relevant to create mechanisms that provide the necessary coordination between the various 
institutional stakeholders, with a view to present progress reports in a number of different fora in which the implementation of the 2030 Agenda is discussed. On the other hand, the EU's impact outside its borders is not limited to its external action agenda. Many EU policies contribute to the implementation of the SDGs worldwide. Therefore, achieving coherence across all EU policies is crucial to achieving the SDGs. With respect to bilateral and multilateral donor programs, the centerpiece of USAID's climate change policy is the Climate Change Initiative (CCI) with projects in three target areas, reducing GHGs, increasing developing countries' participation in UNFCCC, and decreasing vulnerability. The Canadian Government also established the Climate Change Development Fund (CCDF) in 2000, which allocates US\$100 million to assisting developing countries combat the causes and effects of climate change. The CCDF has four priority areas, namely emissions reduction, carbon sequestration, adaptation, and capacity building. Key recipients for the emission reduction include Brazil, China, Egypt, India, Kazakhstan, Nigeria, and South Africa (37-42\% of funds), while the key recipients for adaptation are Bangladesh, sub-Saharan Africa, and Small Island States (10-15\% of funds) (Climate change 2016). Thus, for Nigeria to remain a beneficiary of these foreign aids and attract foreign investment to complement her efforts, she must align her policy frameworks to SDGs to meet international standards in terms of harmonization of policies and legality of initiatives while keying into the priority project target areas set by donor countries and agencies.

In sum, poverty-induced climate change is widespread and has become a global phenomenon which requires international commitments for it to be curbed through adaptation mechanism. The aforementioned efforts have provided the global community with a template for the implementation of adaptation mechanism. In all of these, it will be interesting to examine how Nigeria has fared in employing adaptation mechanism, and this will form the subject of discussion for subsequent segments of this chapter.

\section{Policy, Legal, and Institutional Frameworks for Fighting Poverty in Nigeria}

Nigeria can boast of numerous policies, legal, and institutional frameworks which directly and indirectly deal with climate change and poverty reduction. The frameworks for alleviating poverty in Nigeria include:

(i) Nigeria's Constitution, particularly its chapters II and IV on the protection of citizen's right and the Directive principles of state policy.

(ii) Nigeria Climate Change Policy Response and Strategy: The focus of the policy is to:

(a) Implement mitigation measures that will promote low carbon as well as sustainable and high economic growth

(b) Enhance national capacity to adapt to climate change 
(c) Strengthen national institutions and mechanisms (policy, legislative, and economic) to establish a suitable and functional framework for climate change governance

(iii) The National Adaptation Strategy and Plan of Action on Climate Change for Nigeria (NASPA-CCN). This is the principal National Adaptation Strategy and Plan of Action on Climate Change for Nigeria. The objective of the policy is to integrate climate change adaptation into national, sectoral, state, and local government planning and into the plans of universities, research, and educational organizations, civil society organizations, the private sector, and the media; mobilize communities for climate change adaptation actions through the provision of appropriate user-friendly information; and reduce the impacts of climate change on key sectors and vulnerable communities, among others. Specifically, with respect to agriculture (crops and livestock), the policy seeks to adopt improved agricultural systems for both crops and livestock and to provide early warning/meteorological forecasts and related information.

(iv) The National Policy on Environment which supports "the prevention and management of natural disasters such as floods, drought, and desertification."

(v) Nigeria's Agricultural Policy whose objectives include the protection of "agricultural land resources from drought, desert encroachment, soil erosion, and floods."

(vi) The Nationally Determined Contributions (NDC) which is a determined contribution of Nigeria as regards her target of carbon emission reduction.

(vii) Nigeria's Drought Preparedness Plan.

(viii) National Policy on Erosion and Flood Control.

(ix) National Water Policy, National Forest Policy.

(x) National Health Policy.

(xi) Nigeria's Sovereign Green Bond - Nigeria embraced the issuance of its Sovereign Green Bonds as an innovative and alternate way of raising finance both locally and internationally. This is a financing mechanism to facilitate and assist Nigeria meet its Nationally Determined Contribution target and low carbon pathway for socio-economic development in line with the Economic Recovery Growth Plan (ERGP).

(xii) Development of Sectoral Action Plan for Nationally Determined Contribution (NDC) implementation road map.

(xiii) Other programs/efforts are as follows:

(a) Energizing Education Program(EEP) for seven universities in Ebonyi, Delta, Anambra, Sokoto, Kano, Benue, and Bauchi states at the cost of $\mathrm{N} 8,553,600,827.75$ for 12.5 MW (off grid).

(b) Afforestation programs in Borno, Bauchi, Gombe, Jigawa, Kastina, Adamawa, Kano, Oyo, Plateau, Zamfara, Kaduna, Niger, Oyo, Ondo, Ogun, Abia, and Edo States for N1, 990,331,366.00 covering $1178 \mathrm{Ha}$.

(c) Renewable Energy Micro Utility (REMU) at Sokoto for N146, $067,806.25$ for $60 \mathrm{KW}$ (grid connected). 
(d) National Trader Moni program under which low income business people are given interest free sum of ten thousand (to inject into their businesses) repayable over a specified period.

(e) Establishment of Climate Change Desk Officers across the states of the federation.

(f) Commencement of the implementation of the NDC with the support of UNDP.

(g) Capacity Building on Measurement, Reporting and Verification (MRV) and GHG Inventory achieved on sector mapping.

(xiv) Nigeria has a number of bilateral and multilateral agreement cooperation with World Bank, Global Environment Fund (GEF) Green Climate Fund (GCF), etc.

In striving to address poverty, it is important to note that significant portions of Nigeria's population and economy are tied to activities that are climate sensitive, such as rain-fed agriculture, livestock rearing, fisheries, and forest products extraction. The heavily populated coastal areas and Northern Sahel zone are particularly vulnerable to climate change. As part of efforts to address this vulnerability, Nigeria, in June 2014, in Equatorial Guinea, together with the Heads of State and Government of the African Union put agriculture on top of Africa's agenda when they adopted the Malabo Declaration on Accelerated Agricultural Growth and Transformation for Shared Prosperity and Improved Livelihoods (Malabo Declaration 2014). In the Declaration, African leaders made several commitments, among them, to end hunger in Africa by 2025.

The discussions above reveal that Nigeria has been making domestic and international efforts at adaptation mechanism and to attain SDGs targets. She has also keyed into bilateral, multinational, and regional initiatives. Although there are policy framework arrangements to manage climate change in Nigeria, in reality, the policies are not harmonized and remain mostly on paper. This is because the legal framework specific to climate change is non-existent and therefore not legally binding. Efforts to manage climate change therefore remain ad hoc and superficial. This is due mainly to the fact that Nigeria has failed to establish a robust climate change law that should incorporate some of the global initiatives and best practices enumerated earlier. This leads us to the need to x-ray the legal issues, challenges, and strategies in the application of climate change adaptation mechanism.

\section{Legal Issues, Challenges, and Strategies in the Application of Climate Change Adaptation Mechanism}

There are many legal issues and challenges which hamper the application of climate change adaptation mechanisms in Nigeria. These are examined in this section with a view to proffering strategies to overcome them. 
(i) Lack of legal framework: In Nigeria, there is the National Adaptation Strategy and Plan of Action on Climate Change for Nigeria (NASPA-CCN) and the Nigeria Climate Change Policy Response and Strategy (NCCPRS). Nevertheless, despite the well acknowledged position that there is a close nexus between poverty (SDG 1) and climate change adaptation mechanism as earlier articulated in this chapter, Nigeria still lacks the legally binding law on the subject matter. It has been argued at different fora that the non-transmission of the policies into Nigerian laws is in breach of the climate change policy thrust. This is a challenge and one which makes it difficult to assess the effectiveness of such policies. It has however been suggested in some quarters that the birth of Nigeria's Intended Nationally Determined Contribution (INDC) will compel Nigeria to expedite action on establishing relevant laws and become more focused in terms of combating the impact of climate change. Unfortunately, the provisions of the INDC do not appear to have reflected this expectation.

Furthermore, apart from the absence of a law on climate change to galvanize action toward effective policy implementation, there is equally no existing law in Nigeria that provides for climate change management. In fact, until very recently actions taken by the Ministry of Environment Department of Climate Change have been largely ad hoc and divorced from a bigger picture of global fight against climate change. This is due largely to the absence of a climate change law that will regulate the management of every impact of climate change. The challenge is that without a binding climate change law, it will be difficult to achieve effective adaptation mechanism to reduce poverty in line with the SDGs. In terms of strategy to overcome this challenge, therefore, there is the need to establish a legal framework that would comprehensively and legally bind the various policies on adaptation mechanism. This, for example, is the case in Bangladesh which is a good example of the impact a climate change law can have in the struggle to achieve SDG1.

(ii) Lack of equality: It has been argued in some quarters that calls to eradicate poverty are meaningless without commensurate and committed policy action to reduce inequality. This is a global menace that must be conquered to stand a good chance of meeting the SDG 1 target. For instance, the income of the poorest $20 \%$ of the world's population has only moved from USD \$0.94 in 1990 to $\$ 1.90$ today, but that of the rest of the population has grown from an average USD $\$ 12.85$ to $\$ 18.63$ over the same period, thus creating great inequality. This inequality is projected to worsen with an income gap of USD $\$ 18.79$ by 2030 which is almost double what it was in 1990 (Hope 2018). A recent report by the research organization, Development Initiatives, which looked at the period between 2010 and 2017, found that notwithstanding global commitments to zero poverty as per SDG 1, the attitude of the global actors is at variance with the espoused commitment. Aid donors promised in 1970 to give $0.7 \%$ of their GNI to fighting poverty, and yet the average spent up till 2017 is about $0.31 \%$, and this is lower than it was then $(0.33 \%)$ (Ibid).

In Africa where the population is expanding at a rate of more than $2 \%$ per year, a combination of double digit GDP growth and dramatic declines in 
inequality is a sine qua non for plummeting the level of extreme poverty to below $5 \%$ by 2030 and much more than would be expected to bring the level of poverty to $0 \%$ by 2030 . Corroborating this view, the UN estimates that without significant changes in behavior, more than $7 \%$ of the global population may remain in poverty by the year 2030 , including about $30 \%$ of the populations in Africa and the least developed countries (LDCs). The challenge is for the governments, including the Nigerian government, to bridge this poverty gap.

Since equality is a sine qua non to the attainment of SDG 1, a major strategy should therefore be to ensure that equality is an inclusive part of the fight to eradicate poverty. It is vital that any form of mainstreaming incorporates a poverty focus rather than viewing it as a purely environmental problem. This will ensure that aid initiatives address the vulnerability of the poor to climate changes and equally to align such aids with the priorities of the SDGs. Development partners must continue to support efforts to bridge the poverty gap and to eradicate poverty. In 2010, the International Development Association (IDA) gave almost USD \$2 billion more in loans to middle-income countries (MICs) than to the LDCs, whereas in 2017, it gave over USD \$2 billion more in loans to LDCs than to MICs (Dodd et al. 2019). A research also found that if actors met their commitments, an extra USD \$1.5tn would be available between 2017 and 2030 to help lift the very poorest in the world out of poverty. A number of both bilateral and multilateral donors are driving these trends.

While there is no one-size-fits-all policy prescription that guarantees delivery of a more equal and prosperous society, one overarching message resonates. It is that calls to exterminate poverty are meaningless without concerted and committed policy action for dramatic decrease in inequalities (Zhenmin 2019), in income, in opportunity, in exposure to risk across gender, within countries and between countries. No doubt, well-designed fiscal policies can help smooth the business cycle, provide public goods, enact reforms that would help build resilience, correct market failures which include, for example, raising potential economic growth and its inclusiveness, and directly influencing the income distribution to bridge inequality. Specifically, Nigeria could introduce measures to bring all the poor under coverage of social protection system and antipoverty strategy of the government through, for example, an expanded Social Safety Net Programmes (SSNP) to address risk and vulnerability as a means of reducing poverty and inequality.

(iii) Inadequate political willpower: This entails the lack of sufficient political willpower of government to ensure SDG 1 succeeds, and the inability to elevate SDGs to a very high political level to be able to give it the national attention and priority that climate change issues deserve. Presently, Nigeria does not even have a climate change law to give focus to the fight against climate change. Meanwhile, the political will of the government as good leadership and governance are crucial for implementation of adaptation mechanism. Akin to this is the fact that Nigeria has also not created the favorable climate environment for addressing its long-standing armed conflict or civil unrest, kidnapping, and 
political instability. This means that decent jobs for most citizens will become increasingly out of reach resulting in weak economic performance. The required strategy to address the problem is for the government to muster enough political courage to elevate critical decision-making for climate change matters to the presidency for needed priority and implementation directives.

(iv) Centralization of information and services on climate change: The issue of centralization of information and services at the Ministry of Environment and several other ministries without decentralizing to the door steps of the citizens remains a challenge. This is because adaptation is likely to be successful if people are informed about climate change, how it affects them, and options for doing something about it. Successful climate change interventions are dependent on high-quality accessible information to allow effective decision-making. As the impacts of climate change are difficult to predict accurately, adaptation activities need to be flexible and responsive to new information, and robust enough to withstand a wide range of plausible futures.

There are many examples of use of information to enhance adaptation mechanism. For instance, the use of risk management and coping thresholds is an area of applied adaptation research of growing importance (Part 2: Adaptation). In addition, agricultural climate information is now used to advise farmers about their choice of crops and methods of cultivation, which in turn has provided major benefits in terms of increased yields and preventing food shortages. Similarly, better information and early warning systems for farmers can reduce vulnerability to inter-annual climate variations and enable responses to be proactive rather than reactive. Climate information can generate substantial benefits in other areas as well, including water management, planning and delivery of health services, and improved warning for extreme weather events. The challenge for Nigeria is that in spite of what is provided for in its Nationally Determined Contribution (NDC), Nigeria has failed to decentralize the delivery of public services and take them to the doorsteps of millions of underserved citizens. It has also not actively leveraged the local knowledge of the communities. For example, in Arochukwu, in the Eastern part of Nigeria, farmers can predict a bountiful harvest merely by observing how severe the harmattan is. This highlights the importance of capturing local knowledge, reviewing and assessing its applicability, and its dissemination among other communities and relevant agencies. The strategy to overcome this challenge is to decentralize information. As the poor already have a lot of knowledge about how to cope with climate variability, adaptation activities should take account of this knowledge, where benefits are proven. Incorporating local knowledge into policy actions could help the governments of Nigeria to accommodate specific needs of poor people and ensure that strategies are taken up by local communities. Thus, relevant information must be decentralized from top to the local levels as a matter of deliberate policy.

(v) Weak human and institutional capacity: In Nigeria there is weak human and institutional capacity for climate change related issues. This is because climate change is fast altering the landscapes, and the inability of the various 
government institutions and weak human capacity to respond appropriately has created various risks due to shortages of resources such as land (Orie 2015) and water, with attendant negative secondary impacts, hunger, poverty, sickness, loss of employment, etc. The poor responses have in turn opened the door to conflict. This alteration comes mainly from the arid north; Nigeria's northern Sahel area (the transition zone between the Sahara desert to the north and the grasslands to the south) gets less than 10 inches of rainfall a year already, a full $25 \%$ less than 30 years ago; areas of southern Nigeria where recorded volumes of torrential rains increased $20 \%$ across various southern states, some of which already see up to 160 inches of rainfall a year, with wet seasons lasting 810 months (Odjugo 2005), and along the southern coastline, where sea levels could rise 1.5-3 feet by century's end which is a further increase over the nearly 1-foot rise observed in the last 50 years (Federal Ministry of Environment 2009). (Federal Ministry of Environment, Nigeria and Climate Change: Road to Cop15 (Abuja, Federal Ministry of Environment 2009).) In fact, in 2012 about 26 out of 36 states in Nigeria were submerged in flood water. The situation is getting worse due to inadequate experts and institutions to properly contend with the developments. In Nigeria, there is no conscious effort either toward manpower or institutional development. Most discussions on the impacts of climate change end at the federal level, occasionally at state level but never at the local government level. The implication of this is that there is disconnect between what happens at the federal and state levels and that of the local government. The result is that at the local level people are not motivated to share in the national vision. For example, the locals still engage in illegal sand mining resulting in erosion, land-slides, and other negative impacts on the ecosystem, while at the federal level government is fighting erosion and landslides.

The strategy to checkmate this challenge is to improve human and institutional capacity development at the grassroot level such that a culture of comprehensive risk reduction management would naturally evolve overtime as the locals become stakeholders and team players with the government. Government and private actors also need to ensure that particular adaptive responses do not themselves fuel violence but actively help build peace. Successful adaptation measures will be crosscutting in design and impact, based on inclusive planning and implementation and steer clear of political patronage traps. An example is the system of Payment for Ecological Services (PES) (Fagbohun and Orie 2015).

(vi) Inadequate needs assessment and financing strategy: This is a challenge that cuts across the various adaptation mechanisms. It is so because adaptation as a mechanism is not cheap and therefore requires a lot of funding which most of the developing countries like Nigeria do not have. For instance, for the adaptation mechanism to play its role in achieving SDG1, there must be technology transfer from the developed countries to the developing countries, and also data have to be purchased. In the last couple of years, China has been championing transfer of technology through South-South Cooperation. So many member 
countries of the South-South Cooperation like Bangladesh, Kenya, Ethiopia, South Africa, Angola, etc. have benefitted richly from this collaboration compared to Nigeria. Some of the identified areas are water resources, agriculture, tourism and health, etc. Nigeria should reposition itself to aggressively acquire the much needed technology to adapt to climate change scenarios. No doubt, recent years have seen evidence of China's technical assistance to Nigeria. The argument here is that such assistance would have been much more both in volume and quality had Nigeria been more proactive like some other member countries like Bangladesh and Kenya where CC is elevated to a political level.

In addition, Nigeria is also expected to have done its needs assessment and financing strategy which should be in tandem with its SDG 1. Such an assessment will ensure that aids initiatives address the vulnerability of the poor to climate changes and equally to align such aids with the priorities of achieving SDGs 1 . However, the overriding challenge is that without a strong legal framework on climate change, the international community may not be willing to provide substantial aids. Thus, the strategy to overcome this challenge is to do adequate needs assessment and financial strategy, as well as have a CC law in place in order to attract the international community to support Nigeria fully in its adaptation mechanism to attain SDG 1.

\section{Conclusion and Recommendation}

In response to achieving the global target of SDG 1 by employing adaptation mechanisms, this chapter examined the legal angle to Nigeria's efforts at combating poverty. This was predicated on World Poverty Clock data that by 2018, Nigeria had the largest extreme poverty population of 86.9 million implying that the people are vulnerable to malnutrition, armed conflict, migration, and other socioeconomic and environmental shocks. It was argued that unfortunately for Nigeria, her adaptation efforts are inadequate to ensure the eradication of poverty by 2030. Consequently, Nigeria needs a comprehensive legal framework which is in line with global best practices to enhance her chances of attaining the objective of SDG 1.

The chapter also established the nexus between climate change adaptation mechanism and poverty reduction, showing a direct positive relationship, such that as climate change-induced poverty occurs, the adaptation measures alleviate the adverse consequences and thus make the attainment of SDG 1 feasible. Conversely, weak adaptation mechanism cannot effectively combat the impacts of climate change and invariably undermines the attainment of SDG 1.

It was shown that although there is a policy framework arrangement to manage climate change in Nigeria, in reality, the policies are not harmonized and remain mostly on paper. This is because the legal framework specific to climate change is non-existent and the various related policies are not legally binding. Efforts to manage climate change remain ad hoc and superficial. Therefore, a way forward was proffered based on some global best practices which Nigeria could leverage in the implementation of adaptation laws. 
The legal issues and challenges militating against Nigeria's efforts at effectively employing adaptation mechanisms were discussed. They include lack of legal framework, inequality, inadequate political will, and centralization of information and services. Others are weak human and institutional capacities and lack of needs assessment and financing strategy regarding adaptation mechanism. These challenges were matched with corresponding and relevant strategies which include establishment of a robust climate change law which ought to draw from global best practices and incorporate the extant regulations and policies, curbing inequality through the introduction of social protection system and anti-poverty strategy for the poor to address risk and vulnerability. In addition, the law must provide for climate change and related issues to be elevated to a political level such that government shall muster the necessary political will to domicile climate change related issues at the presidency and give top priority to such issues. Other strategies are decentralization of information down to citizens at the local government level, human and institutional capacity building, and undertaking of needs assessment and financing strategy. The chapter therefore makes the following recommendations.

The chapter thus recommends the establishment of climate change law in Nigeria that incorporates adaptation measures and mainstreaming of climate change issues towards the attainment of SDG 1. This law should be comprehensive enough to give legal backing to the various extant policies. It should cover social protection system and anti-poverty strategy for the poor to address risk and vulnerability; elevation of critical climate change decision-making to the presidency in order to get priority attention and the needed funding; as well as decentralization of information down to citizens at the local government level. Provisions should also be made for periodic training of staff and reform of institutions to effectively undertake climate change and adaptation projects. Significantly, needs assessment and financing strategy should be undertaken to the standards required by development partners and aid givers to attract the necessary levels of foreign funds and maintain transparency and accountability. These recommendations constitute the legal imperatives to properly regulate institutional and policy interventions to impacts of climate change and if implemented will guarantee attainment of SDG 1 by 2030 and thereby enhance poverty reduction in Nigeria.

\section{References}

Addis Ababa Action Agenda - the United Nations (2005). Available https://www.un.org/esa/ffd/ ffd3/press. . ./countries-reach-historic-agreement.html

Addis Ababa Action Agenda of the Third International Conference on Financing for Development (Addis Ababa Action Agenda) 2015 (endorsed by the General Assembly in its resolution 69/313 of 27 July 2015). Available https://www.un.org/esa/ffd/ffd3/press $\% \mathrm{E} 2 \% 80 \% \mathrm{~A} 6 /$ countriesreach-historic-agreement.html

Atkinson AB (2016) Monitoring global poverty. Report of the commission on global poverty. World Bank Group, Washington, DC. Available https://openknowledge.worldbank.org/

Ban Ki-Moon United Nations Millennium Development Goals - the United Nations. Available https://www.un.org/millenniumgoals/ 
Bankoff G (1999) A history of poverty: the politics of natural disasters in the Philippines, 19851995. Pac Rev 12(3):8-12

Chen S, Ravallion M (2010) The developing world is poorer than we thought, but no less successful in the fight against poverty. Q J Econ 125(4):1577-1625

CIDA (2001) Canada climate change development fund management framework and business plan. Available cida.gc.ca/cida_ind.nsf/c868c8f732a05e34852565a20067581f/ f5036f5adbab9c3385256ad10073ea48? OpenDocument

Climate change is a threat - and an opportunity... (2016) World Bank Group. Available www. worldbank.org/. . ./climate-change-is-a-threat $\% 2 \mathrm{D} \% 2 \mathrm{D}$-and-an-opportunity $\% 2 \mathrm{D} \% 2 \mathrm{D}$-for-thepri...

DFID (2000) Achieving sustainability: poverty elimination and the environment. Available www. albacharia.ma/.../1575Target_Strategy_Paper_Achieving_sustainability_-pover...

DFID, EC, UNDP, World Bank (2002) Linking poverty reduction and environmental management: policy challenges and opportunities, consultation draft of discussion document. DFID, EC, UNDP, World Bank, London/Brussels/New York/Washington. Available documents. worldbank.org/curated/en/347841468766173173/pdf/multi0page.pdf

Dodd et al (2019) Six ways to refocus ODA to end poverty and meet the SDGs. Available devinit. org/post/refocus-oda-end-poverty-meet-sdgs/

Ending Extreme Poverty and Promoting Shared Prosperity (2013) World bank News. Available www.worldbank.org, news, feature, 2013/04/17

European consensus on development | International (2017) European Commission- Fact Sheet. Available ec.europa.eu international-partnerships european-co

Fagbohun OA, Orie EG (2015) Nigeria: law and policy issues in climate change, ELRI, monograph series. Available https://kdp.amazon.com/en_US/bookshelf?laguage=en_US

Federal Ministry of Environment (2009) Nigeria and climate change: road to Cop15 Abuja Federal Ministry of Environment

Fiszbein A, Schady N (2009) Conditional cash transfers. World Bank policy research report. Available http://siteresources.worldbank.org/intcct/resources/5757608-1234228266004/prrcct-web-noembargo.pdf

Global climate change: vital signs of the planet|precipitation. . Available https://pmm.nasa.gov/ education/websites/global-climate-change-vital-signs-planet

Gomez-Echeverri L (2018) Climate and development: enhancing impact through stronger linkages in the implementation of the Paris agreement and the Sustainable Development Goals (SDGs). Phil Trans R Soc A 376(2119):20160444. https://doi.org/10.1098/rsta.2016.0444

Gurtner B (2010) The financial and economic crisis and developing countries. Available https:// journals.openedition.org/poldev/144

Hope A (2018) Launch: investments to end poverty 2018 - development initiatives. Available devinit.org/post/launch-investments-to-end-poverty-2018/

IPCC (1995) Climate change: intergovernmental panel on climate change. Cambridge University Press, Cambridge. Available https://ipcc.ch/ipccreports/tar/wg1/index.php?idp=47

IPCC 2001 - IPCC. Available https://www.ipcc.ch/2001/

IPCC report 2014 fifth assessment report - IPCC. Available https://www.ipcc.ch/assessment-report/ $\operatorname{ar} 5 / \mathrm{B}$

Kelman (2017) Linking disaster risk reduction, climate change, and the sustainable development goals. Disaster Prev Manag: Int J 26(3):254-258. https://doi.org/10.1108/DPM-02-2017-0043

Lipper L et al (2014) Climate-smart agriculture for food security. Nat Clim Change 4(12):10681072

Malabo declaration on accelerated agricultural growth and transformation for shared prosperity and improved livelihoods (2014). Available https://www.resakss.org/sites/default/files/Malabo\% 20Declaration\%20on\%20Agriculture_2014_11\%2026-.pdf

McGuigan $\mathrm{C}$ et al (2002) Poverty and climate change: assessing impacts in developing countries and the initiatives of the international community. Available https:/www.odi.org/sites/odi.org. uk/files/odi-assets/publications-opinion-files/3449.pdf 
Medugu NI et al (2011) Drought and desertification management in arid and semi-arid zones of Northern Nigeria'. Emerald Manag Environ Q 22(5):610. Available www.fao.org/3/aad710e.pdf. 2003

Messer NM (2003) The role of local institutions and their interaction in disaster risk... Available www.fao.org

National adaptation strategy and plan of action on climate... - CSDevNet csdevnet.org/.../ NATIONAL-ADAPTATION-STRATEGY-AND-PLAN-OF-ACTION. . .

Odjugo PAO (2005) An analysis of rainfall pattern in Nigeria (2005). Global J Environ Sci 4(2):139-145

Olabode PO et al (2015) Determinants of poverty level in Nigeria. J Sustain Dev 8:1

Olawale S (2018) Nigeria poverty statistics and poverty rate in Nigeria - NaijaQuest.Com. Available https://naijaquest.com/nigeria-poverty-statistics/. 5 Feb 2018

Olofin, Adejumo \& Sanusi (2015) Determinants of Poverty Level in Nigeria. Journal of Sustainable Development 8(1):235-241. Available https://doi.org/10.5539/jsd.v8n1p235

Olsthoorn et al (1999) The Netherlands, always vulnerable to floods, has a new approach to... Available https://www.pri.org/. . /netherlands-always-vulnerable-floods-has-new-approachwater...

Orie EG (2015) Climate change and sustainable development: the Nigerian legal experience. NOUN Curr Issues Nigerian Law 5:68-114

Orie EG (2017) Legal perspective to the mitigation of impact of climate change in Nigeria. Univ Jos Law J 12(1):323-344

Parnell S (2017) Africa's urban risk and resilience. Int J Disaster Risk Reduct 26:1-6

Part 2: Adaptation lessons from past experience-OECD.org. Available https://www.oecd.org/env/ cc/4494574.pdf

Portugal Sustainable Development Knowledge Platform (2016). Available https://sustainablede velopment.un.org/memberstates/portugal

Poverty and Climate Change - odi.org. Available https://www.odi.org/resources/docs/3449.pdf

Poverty|United Nations Educational, Scientific and Cultural. ... Available www.unesco.org/new/en/ social-and-human-sciences/. . ./international. . ./poverty/

Report of the conference of parties on its seventh session held at Marrakesh from 29th October to 10th November 2001: part II - action taken by the conference of parties. Available https:// unfccc.int/node $/ 2516$

Roser M, Ortiz-Ospina E (2019) Global extreme poverty - our world in data. Available https:// ourworldindata.org/extreme-poverty

Sayne A (2011) Climate change adaptation and conflict in Nigeria, United States Institute of Peace Special Report. Available http://www.usip.org/sites/default/files/Climate

Smucker TA et al (2015) Differentiated livelihoods, local institutions, and the adaptation imperative: assessing climate change adaptation policy in Tanzania. Geoforum 59:39-50

Standing Orders on Disaster (2010) - PreventionWeb. Available https://www.preventionweb.net/ files/18240_sodapprovedbyndmb.pdf

Sustainable Development, Poverty Eradication and Reducing... - IPCC. Available https://report. ipcc.ch/sr15/pdf/sr15_chapter5.pdf

The global extreme poverty- our world in data. Available https://ourworldindata.org/happiness-andlife-satisfaction/

The Sustainable Development Goals Report 2018|Multimedia Library. . Available https://www.un. org/development/. . . publications/the-sustainable-development-goals-re...

The World Bank research report (2015) A measured approach to ending poverty and boosting shared prosperity: concepts, data, and the twin goals. World Bank, Washington, DC, pp 37, 38

United Nations Framework Convention on Climate Change. Available http://environment-ecology. com/climate-change.html

Weisser F (2014) Translating the adaptation to climate change paradigm: the politics of a travelling idea in Africa. Geogr J 180(2):111-119

World Bank (1990) World development report, poverty. Oxford University Press, New York 
Zhenmin L (2019) Ending poverty is possible, but it means facing up to inequality - within \& between countries INTER PRESS SERVICE. Available http://www.ipsnew

Open Access This chapter is licensed under the terms of the Creative Commons Attribution 4.0 International License (http://creativecommons.org/licenses/by/4.0/), which permits use, sharing, adaptation, distribution and reproduction in any medium or format, as long as you give appropriate credit to the original author(s) and the source, provide a link to the Creative Commons license and indicate if changes were made.

The images or other third party material in this chapter are included in the chapter's Creative Commons license, unless indicated otherwise in a credit line to the material. If material is not included in the chapter's Creative Commons license and your intended use is not permitted by statutory regulation or exceeds the permitted use, you will need to obtain permission directly from the copyright holder.

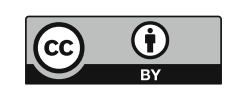

